areas where the effect is likely to be greatest. Mr. Sanford D. Cole described the Wheeler system by which the cleaning out of oil tanks, double bottoms and bilges is carried out mechanically and much more efficiently than by hand, and suggested that the installation at various ports of separator barges fitted with this American contrivance might go far to diminish the evil of oil pollution.

\section{Sea Shells from Victoria}

Tre Field Naturalists' Club of Victoria is designing a series of handbooks to foster interest in the State's fauna and flora. The second of the series is by C. J. Gabriel, honorary conchologist, National Museum, Melbourne; it is entitled "Victorian Sea Shells, a Handbook for Collectors and Students", and has been published by the Field Naturalists' Club of Victoria (price 1s. 6d.). It is well illustrated by Joyce K. Allan, assistant conchologist, Australian Museum, Sydney, with a coloured and several uncoloured plates. Descriptions are given of most of the common sea shells around the coast of Victoria. From a collector's point of view, this little work is extremely useful and will help many to name their specimens. It does not, however, attempt to teach anything about the animals themselves beyond their various habitats. A popular name is given to each shell, in most cases a translation of the specific name. Thus we have the "impoverished Nassarius" and the "sordid sand snail", but there is the banded periwinkle, also known as the "Austral wink", and the black nerite, also known as the "crow". There are a dictionary of terms and diagrams showing the different parts of the shell.

\section{World Congress of Faiths}

THE World Congress of Faiths, of which Sir Francis Younghusband is chairman, is arranging a week-end Congress to be held at Cambridge on June 24-28, with residence for men at St. John's College and for women at Newnham College. The subject for deliberation will be "The Renaissance of Religion". Distinguished speakers, representing religions, philosophy and science, will deliver addresses to be followed by discussion. The object for which the World Congress of Faiths is organized is to promote a spirit of fellowship among mankind through religion. The Congress seeks to awaken and develop a world-loyalty, whilst allowing full play for the diversity of men, nations and faiths. Further particulars may be obtained from the secretary, World Congress of Faiths, 36 Victoria Street, London, S.W.1.

\section{Announcements}

The Most Reverend Cardinal Arthur Hinsley, Archbishop of Westminster; Prof. J. Chadwick, professor of physics in the University of Liverpool ; and Sir Richard Livingstone, president of Corpus Christi College, Oxford, since 1933 and Vice-Chancellor of the Queen's University, Belfast, in 1924-1933, have been elected members of the Athenæum under the provisions of the rule of the club which empowers the annual election by the Committee of a certain number of persons of distinguished eminence in science, literature, the arts, or for their public services.

H.M. THE KING has approved the award of the Royal gold medal of the Royal Institute of British Architects to Mr. Ivar Tengbom (Sweden), hon. corresponding member, in recognition of the merit of his work as an architect. The medal will be presented to $\mathrm{Mr}$. Tengbom at a general meeting of the Institute on April 4.

THE following officers of the Royal Astronomical Society were elected at the anniversary meeting of the Society on February 11 : President, Dr. H. Spencer Jones, Astronomer Royal ; Vice-Presidents, Prof. S. Chapman, Prof. H. Dingle, Sir Frank Dyson and Prof. F. J. M. Stratton; Treasurer, Mr. J. H. Reynolds ; Secretaries, Prof. W. M. H. Greaves, Prof. H. H. Plaskett; Foreign Secretary, Sir Arthur Eddington.

IN connexion with the movement for the preservation of the fauna and flora of the Empire, attention has been directed to the imperfection of our knowledge of the fauna and flora of Fiji and the Western Pacific High Commission Territories. These Governments have recently expressed the hope that the subject will attract more attention in future. Adequately qualified naturalists desirous of devoting a fow months to such studies in these territories under favourable conditions should consult the Under Secretary of State, Colonial Office, Downing Street, S.W.1.

Prof. GÜNTHer ENDERLEIN, the well-known Berlin entomologist and bacteriologist, has recently retired on reaching the age limit.

Prof. Hans Buraer, director of the psychiatric and neurological clinic at the University of Jena, has been nominated a member of the Kaiser Leopold Caroline German Academy of Natural Science in Halle.

The Gillson scholarship in pathology has been awarded by the Society of Apothecaries of London to Dr. R. H. S. Thompson of the Rockefeller Institute.

THE following appointments and promotions have recently been made in the Colonial Service: Agricultural officers-G. D. Badger, Uganda; T. W. Brown, Malaya; F. E. J. Buller, Nigeria; P. V. Ormiston, Malaya; W. N. Scott, Malaya; A. K. Briant (agricultural superintendent, St. Vincent), Zanzibar; R. P. Davidson (agricultural officer, Uganda), Malaya ; H. P. Smart (agricultural officer, British Honduras), senior agricultural officer, Tanganyika. Other appointments-P. Coryndon, inspector of produce, Nigeria ; F. E. Harnett, sleeping sickness control officer, Nigeria; J. R. O. Humplries, inspector of plants and produce, Gold Coast; D. W. Le Mare, assistant to the director of fisheries, Straits Settlements. 